AGRIEKONOMIKA

http://journal.trunojoyo.ac.id/agriekonomika

Volume 9, Nomor 1, 2020

https://doi.org/10.21107/agriekonomika.v9i1.6856
Agriekonomika has been accredited as a scientific journal by the Ministry of Research-Technology and Higher Education Republic of Indonesia: No. 23/E/KPT/2019

SINTA 2

\title{
Factors Affecting Technology Adoption of Geoisolator on Solar Saltworks in East Java Province
}

\author{
$凶 1,2$ Aminah Happy Moninthofa Ariyani, ${ }^{3}$ Harianto, ${ }^{3}$ Suharno, ${ }^{4}$ Yusman Syaukat \\ ${ }^{1}$ Doctoral Program of Agricultural Economics of IPB University, Indonesia \\ ${ }^{2}$ Department of Agribusiness, Trunojoyo Madura University, Indonesia \\ ${ }^{3}$ Department of Agribusiness, IPB University, Indonesia \\ ${ }^{4}$ Department of Economic Science, IPB University, Indonesia
}

Received: January 2020; Accepted: April 2020; Published: April 2020

\begin{abstract}
Large quantity and high-quality salt are demanded in Indonesia, yet the quality of salt produced by farmers is still low. Increasing salt quantity and quality is possibly done through the implementation of geoisolator technology. This study aimed to investigate factors affecting the decision of salt farmers to adopt geoisolator technology. The study was conducted at the salt production center in Madura Island. A survey on salt farmer was carried out during August-September 2018. A total of 190 respondents consisted of 131 salt farmers who adopted geoisolator technology and 59 traditional salt farmers were selected as a sample in this study. Factors affecting farmer decision to adopt geoisolator technology was analyzed using logit (logistic regression) model. The result of this study showed that the decision of salt farmer to adopt geoisolator technology was affected by the number of productive-age family members and the number of dependent family members, land area, farmer participation in the group, farmer participation in extension. Enhancement in the adoption of geoisolator technology needs synergy between extension agent and salt farmer group so that the mentoring process and knowledge transfer will be achieved.
\end{abstract}

Keywords: Decision, Logit, Logistic Regression, Salt

\section{INTRODUCTION}

Salt is an important raw and auxiliary material in the chemical industry, around 60 percent of the world's salt production is used in this industry (Sedivy, 2009). Along with its rapid industrial development, Indonesia consumes industrial salt of 82.28 percent of the total national salt requirement (Kemenperin, 2018). Hence, the import of industrial salt to meet salt demand is still performed. The salt import is conducted since industrial salt requires $\mathrm{NaCl}$ content of above 95 percent.

Salt produced by salt farmer according to (Adi et al., 2006), only contained $\mathrm{NaCl}$ content of less than 80 percent. The general perception of salt derived from evaporated seawater according to Sedivy (2009), is that the salt considered cheap but dirty and contains a compound that is harmful to the industrial sector. The purity of salt evaporated from seawater produced in India and China reached 99-99.5 percent of $\mathrm{NaCl}$, and purity of salt derived from evaporated seawater produced by Australia and Mexico reached 99.799.8 percent. The production of salt from evaporated seawater may reach a purity of 99.94 percent through the implementation of advanced technology such as biological management, crystallization, harvesting technique, and salt management.

Based on the data obtained from Kementerian Kelauatan dan Perikanan 
(2018), national salt production in 2017 amounted to 1.02 million tons, so that it only meets 40 percent of the total national salt needs. Production increase can be achieved through three actions, namely: (1) increase in efficiency, (2) development and adoption of technology, and (3) exploitation of economic scale or combination of those three actions (Coelli et al., 2005). This shows that several alternatives are possible to solve the problem concerning the fulfillment of the national salt requirement. One of the technologies possibly applied to increase the production and quality of salt derived from evaporated seawater is geomembrane or geoisolator technology. Usage of the term geoisolator by following its inclusion in the Law of the Republic of Indonesia Number 7 of 2016 concerning Protection and Empowerment of Fishermen, Fisheries, and Salt Farmers.

Geoisolator technology is applied by re-designing traditional salt evaporation pond to semi-intensive one that consists of several ponds, namely seawater reservoir, two evaporation ponds, concentration pond, pre-crystallization pond, and crystallization pond. Waterproof plastic (geomembrane) is placed at the base of the crystallization pond to prevent salt produced from soil contact (BPPP Tegal, 2017). Geomembrane, an elastic and strong polymer layer, made of polyethylene and used to avoid liquid loss, consists of several levels of thickness. The advantages of using geomembrane include its resistance to ultraviolet light and chemical material (Scheirs, 2009), the ability to prevent the loss of seawater as salt raw material, and allowing faster crystallization process (Suhendra, 2016).

Implementation of geoisolator technology in the salt production process may help a salt farmer to increase salt production and quality. In addition to a production increase, the price of the 1st quality salt will be higher than the 2nd and 3rd quality. As mentioned by Balde et al. (2013), in his study revealed that the quality of salt produced by farmers using a base in crystallization ponds was found to be higher due to less contaminant.
This condition created such an impact on the higher salt price per sack, thus salt farmers generated higher income than those performing traditionally. Susanto et al. (2015), in his study, salt produced in a pond covered by geomembrane was found to have a higher price with the selling price difference between geomembrane and traditional production reached 30 million rupiahs. Implementation of geoisolator technology that resulted in increasing salt production and quality is expected to also increase salt farmer income. Unfortunately, not all salt farmers have yet to adopt this geoisolator technology.

Technology to increase salt production quality and quantity in the Jepara Regency by modifying the production process of traditional salt using plastic base resulted in increasing salt quantity 67 percent with an increase in $\mathrm{NaCl}$ content from 90 to 98.4 percent (Susanto et al., 2015). Salt production using a plastic base in Sumenep Regency successfully contributed to a larger, clear and white salt crystal with $\mathrm{NaCl}$ content of 94.72 percent or equivalent to the 1st quality of salt, while salt produced through traditional technology was small in size and had an opaque white color with $\mathrm{NaCl}$ content of 81.78 percent or equivalent to the 3 rd quality of salt. Based on those studies, there is a possibility that salt production by SNI can be increased, thus reducing dependence on salt import (Effendy et al., 2011).

Mignouna et al. (2011), reported that household size played role in an adoption process, a household with a greater number of a family member was found to minimize labor requirement constraints in the early stage of modern technology implementation. According to Challa \& Tilahun (2014), family size and farm size significantly affected the adoption of new technology, while Samiee et al. (2009), mentioned that land size did not significantly affect or had a neutral relationship with adoption. Five stages in the innovationdecision process are 1) initial knowledge about innovation; 2) the formation of an attitude to innovation; 3 ) decision making to 
accept or reject innovation; 4) implementing innovation; 5) confirmation of the decision (Rogers, 2003). In this study, is limited to only one stage, namely the innovationdecision stage. A study conducted by Muzari et al. (2012), in Sub-Saharan Africa, showed that factors affecting the adoption of technology included asset, income, institution, labor, and innovation made by farmers. Technology with a higher possibility to be adopted by farmers is a technology that requires fewer assets, lower risk premium, and less expensive. According to (Kumar et al. (2018), the influencing factors on adoption decisions are the price of the product being sought and the expected profit. Farmers are inclined to adopt better technology by looking at higher productivity, lower costs, and ease of use. Geoisolator technology requires additional costs to purchase geomembrane and additional labor for the installation process. The aforementioned causes the technology to be adopted slowly. This study aimed to investigate factors affecting the salt farmer's decision to adopt geoisolator technology.

\section{METHODOLOGY}

This study was conducted on Madura Island. This location was selected through the method of purposive sampling since salt production areas are distributed over all regencies, namely Bangkalan, Sampang, Pamekasan, and Sumenep as they become salt production centers and contribute to 26.3 percent of national salt production. A survey on salt farmer was carried out during August-September 2018.

This study was conducted on Madura Island. This location was selected through the method of purposive sampling since salt production areas are distributed over all regencies, namely Bangkalan, Sampang, Pamekasan, and Sumenep as they become salt production centers and contribute to 26.3 percent of national salt production. A survey on salt farmer was carried out during August-September 2018.

A total of 190 respondents consisted of 131 salt farmers who adopted geoisolator technology and 59 traditional salt farmers were selected as a sample in this study. Traditional farmers were those located in areas closest to geoisolator farmers.

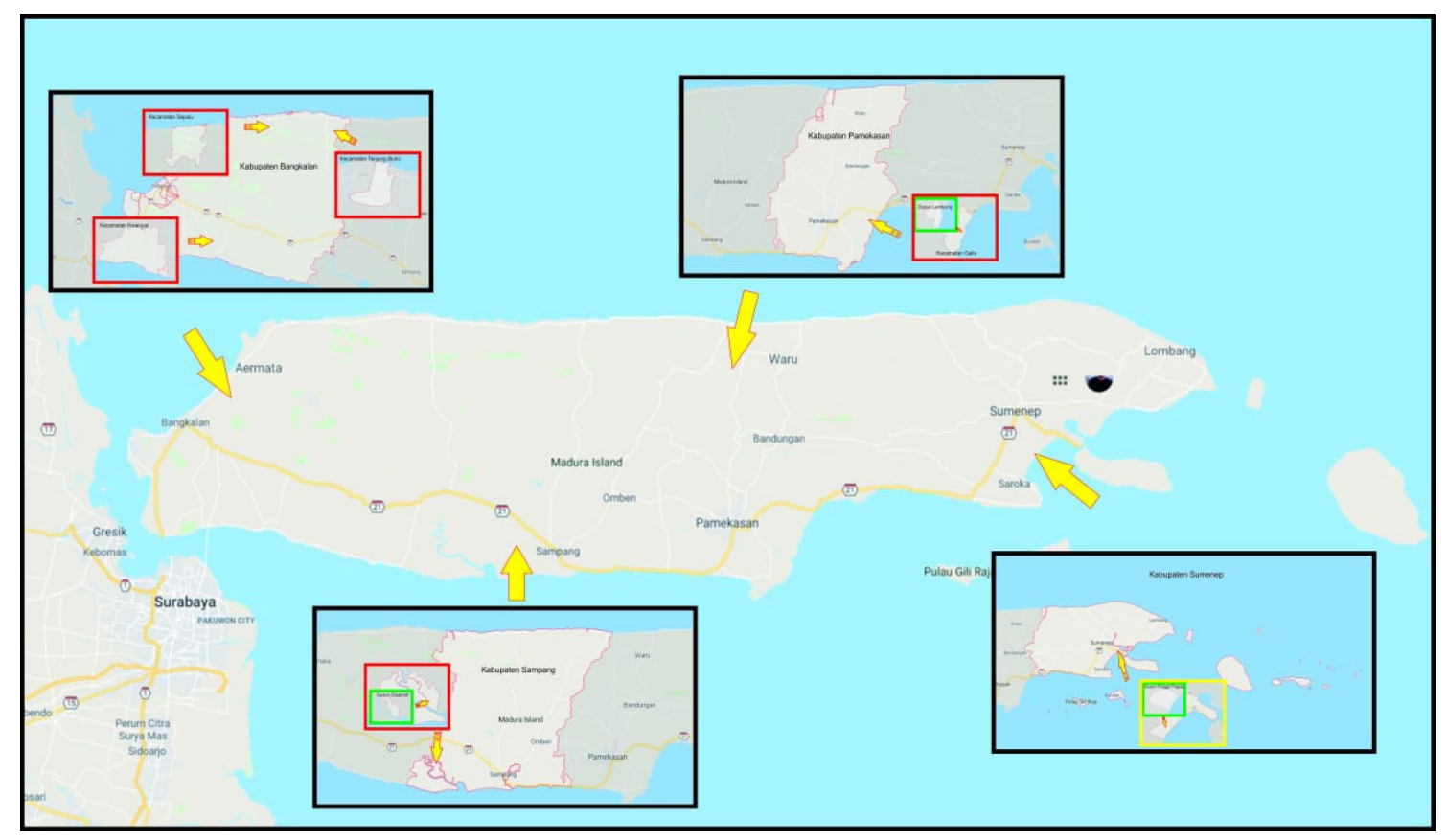

Source: Processed Data (Google Maps, 2019)

Figure 1

Map of the Study Area 
Sampling was conducted using the purposive sampling method for geoisolator farmers, while the sampling for traditional farmers is done by the snowball sampling method.

Factors affecting salt farmer decision to adopt geoisolator technology were analyzed using the logit model. This model analyzes the response of a binary independent variable with a scale value of 1 and 0 . The logit model is expressed as follows.

$\operatorname{Ln} \frac{P_{i}}{1-P_{i}}=\beta_{0}+\beta_{I} x_{1}+\beta_{2} x_{2}+\ldots \ldots \ldots \ldots .+\beta_{i} x_{i}$

Where $\mathbf{P}_{i}$ is the probability of salt farmer to adopt geoisolator technology, $0<\mathrm{Pi}<1, \mathrm{Y}_{\mathrm{i}}$ is geoisolator $(\mathrm{y}=1$ salt farmer who adopts geoisolator technology; $y=0$ salt farmer who does not adopt geoisolator technology), $\mathbf{X}_{\mathrm{i}}$ is the independent variable, $\boldsymbol{\beta}_{0}$ is constant, $\boldsymbol{\beta}_{\mathrm{i}}$ is parameter estimated, e is a natural number (2.7182).

In this study, factors expected to affect the adoption of geoisolator technology consisted of the age of head of a family, number of the educational years completed, experience the head of the family, number of a productive-age family member, number of a dependent family member, salt production area, participation in the group, and participation in extension. The model of logistic regression was processed using Stata 13.

The marginal effect can measure a change in an independent variable that affects a change in the dependent variable, while other variables are considered constant. Marginal effect is obtained from the coefficient estimate of the equation below.

$\delta P i / \delta X i j=P i(1-P i) \beta j$, where $\mathrm{Pi}=\Lambda\left(\mathrm{x}_{\mathrm{i}} \beta\right)$

To observe how well a model explains the relationship between a dependent variable and an independent variable, the goodness of fit test was performed. In logistic regression, the parameter observed for the goodness of fit test is Pseudo R2 that is similar to R-square in linear regression but does not relate to fitting a model to data (Greene, 2012). Pearson goodness of fit testing is done by formal testing of the null hypothesis that the model used is feasible, and the output is a p-value between 0 and 1 , a low p-value (below the 0.05 level) will indicate that the model is unacceptable (Allison, 2014).

\section{RESULTS AND DISCUSSION Characteristics of Salt Farmer and Salt Farming Business}

Indonesian salt farmers are still mostly traditional, while the saltworks technology is highly developed. To improve quality and production, it is necessary to apply geoisolator technology. Generally, salt farmers applying geoisolator technology had less salt farming business experience compared to traditional farmers. Saltfarmers have different business characteristics that influence farmer decisions to adopt geoisolator technology. The head of the family had an average of more than 17 years of salt farming experience. Based on the results of the study, some salt farmers who applied geoisolator technology started a saltworks business after the technology was introduced.

The salt farming area with geoisolator technology was found to be larger than the traditional area. Farmers who applied geoisolator owned land area of 1.36 hectares on average, while traditional farmers only had 1.12 hectares of the salt farming area. About 65.91 percent of salt farmers applied a profit-sharing system in performing a salt farming business, while the rest of 26.36 percent performed business in their land and the other 6.82 percent rented a land area for salt farming. The profit-sharing system mostly applied by salt farmers in research location was profit sharing with a ratio of 50:50, 40:60, or $1: 2$, depending on the agreement made by both parties. A comparison between household characteristics of geoisolator and traditional salt farmers is presented in Table 1. 
Table 1

Comparison the Characteristics Between the Geoisolator and Traditional Salt Farmer

\begin{tabular}{lcccc}
\hline \multirow{2}{*}{ Variable } & \multicolumn{3}{c}{ Mean } & \\
\cline { 2 - 4 } & Geoisolator & Traditional & p-value \\
\hline Age of head of a family & 47.66 & 50.30 & 0.1667 \\
Number of the academic years completed by the & 6.45 & 6.88 & 0.3579 \\
head of a family & & & & \\
Salt farming experience & 17.38 & $*$ & 19.00 & 0.0435 \\
Number of productive-age family members & 1.96 & & 2.40 & 0.1573 \\
Number of dependent family members & 1.02 & & 1.22 & 0.5851 \\
Salt production area & 1.36 & $*$ & 1.12 & 0.0172 \\
Farmer group membership & 0.80 & $*$ & 0.47 & 0.0001 \\
Participation in extension & 0.31 & $*$ & 0.03 & 0.0000 \\
\hline Source:Pimary
\end{tabular}

Source: Primary Data Processed, 2018

Note: * the difference between geoisolator and traditional farmer is significant at $p=0.05$

On average, salt farmers who applied geoisolator technology and traditional had 2 family members at a productive age. Geoisolator technology applied in salt farming resulted in less number of labor required during harvesting due to geomembrane covering, thus farmers harvested their salt faster since the salt is prevented from soil contact.

The average number of geoisolator farmers' membership in the group was found to be higher than that of traditional farmers. Membership in the group of geoisolator farmers was 80 percent, while traditional farmers were only 47 percent. Based on the data obtained in this study, salt farmers on average confirmed that becoming a member of the salt farming group will increase the opportunity to receive government assistance than not being a group member.

On average, the number of salt farmers applying geoisolator technology who participated in extension was higher than that of traditional farmers. participation in the extension of geoisolator farmers was 31 percent, while traditional farmers were only 3 percent. According to the study result, farmers mentioned several reasons such as they were busy performing salt farming in the pond, they received the information on extension activity too late, or the place where extension activity took place was too far. Since there was only one extension worker responsible for several villages, salt farmers could not obtain assistance role and knowledge transfer completely.

\section{Factors Affecting the Decision of Salt Farmer to Adopt Geoisolator Technol- ogy}

The logit model was used to estimate factors affecting the decision of salt farmers to adopt geoisolator technology. The result of the goodness of fit test using Pearson's test showed a statistical probability of chi2 of 0.6165 higher than $\alpha=0.05$, indicating that the logistic regression model is fit to be used in the prediction. The predictive ability of the model resulted in a value of 73.68 percent. The estimated result of factors affecting the salt farmer's decision to adopt geoisolator technology is presented in Table 2.

A partial test of the parameter was done simultaneously. Simultaneous test using a likelihood ratio test resulted in an LR chi2 value of 50.28 with Prob> chi2 of 0.0000 , indicating that independent variables in the model simultaneously affected the decision of salt farmer to adopt geoisolator technology. Partial test performed using the Wald test showed the decision of salt farmer to adopt geoisolator 
Table 2

The Estimate of Factors Affecting Salt Farmer Decision to Apply Geoisolator Technology

\begin{tabular}{|c|c|c|c|c|c|}
\hline Variable & Coeff & & St. Error & $P>|z|$ & Marginal Effect \\
\hline Age of head of a family & -0.0213 & & 0.0249 & 0.394 & -0.0038 \\
\hline $\begin{array}{l}\text { Number of the academic years } \\
\text { completed by the head of a family }\end{array}$ & -0.0842 & & 0.0709 & 0.235 & -0.0151 \\
\hline Salt farming experience & -0.0164 & & 0.0228 & 0.472 & -0.0029 \\
\hline $\begin{array}{l}\text { Number of productive-age family } \\
\text { members }\end{array}$ & -0.3804 & * & 0.2063 & 0.065 & -0.0682 \\
\hline $\begin{array}{l}\text { Number of dependent family } \\
\text { members }\end{array}$ & -0.3355 & * & 0.1972 & 0.089 & -0.0602 \\
\hline Salt production area & 0.7976 & ** & 0.3761 & 0.034 & 0.1430 \\
\hline Farmer group membership & 1.1910 & *** & 0.4170 & 0.004 & 0.2369 \\
\hline Participation in extension & 2.0654 & $* * *$ & 0.8014 & 0.010 & 0.2697 \\
\hline Constant & 1.9001 & & 1.3720 & 0.166 & \\
\hline Log-likelihood & -92.5713 & & LR chi2 & & 50.28 \\
\hline Pearson (Prob>chi2) & 0.6165 & & Prob > chi2 & & 0.0000 \\
\hline Correctly Classified & 0.7368 & & Pseudo R2 & & 0.2136 \\
\hline
\end{tabular}

Note: ${ }^{*}$ Significant at $p<0.10,{ }^{* *}$ Significant at $p<0.05,{ }^{* * *}$ Significant at $p<0.01$

Source: Primary Data Processed

technology was affected by the number of a productive-age family member and the number of dependent family members, land area, farmer group membership, farmers participation in the extension.

The number of productive age family member has a negative and significant effect on technology adoption at $p<0.10$. The marginal effect value of productive age family member is -0.0682 meaning that if the average family member of productive age increases by 1 person, the probability of farmers adopting geoisolator technology decreases by 6.82 percent. Based on observations in the field, productive family members owned by farmers work outside the salt business, so that will reduce the probability of farmers to adopt. This result is contrary to Asmelash (2014) and Beshir et al. (2012) in Ethiopia that the greater the number of productive family members will positively influence adoption because adoption requires intensive labor.

The number of dependents of salt farmer families has a negative and significant effect with $p<0.10$, meaning that the greater the number of dependents owned by the farmer, the probability of salt farmers adopting geoisolator technology will decrease. The marginal effect value of the dependents is -0.0602 , meaning that if the average number of dependents increases by 1 person, the probability of salt farmers adopting geoisolator technology decreases by 6.02 percent. This result is consistent with Kassie et al. (2009) and Beshir et al. (2012) in Ethiopia. Conflicting results expressed by Letaa et al. (2015) in Tanzania and Nazir et al. (2018) in Pakistan because households with a large number of dependents face a higher risk of food insecurity, so adoption can increase opportunities to prevent food insecurity and increase income.

Salt production area obtained a positive coefficient and significantly affected the decision with $p$-value $<0.05$, which means that larger harvesting areas owned by farmers will lead to an increase in the probability of salt farmer to adopt geoisolator technology. The value of the marginal effect of salt pond area reached 0.1430 which means that the 1-hectare increase in the average land area will 
increase 14.30 percent of the probability of salt farmer to adopt geoisolator technology. This finding was consistent with the result of the study conducted by Uaiene et al. (2009) in Mozambique and Hu et al. (2019) in China. Also, Akudugu et al. (2012) and Udimal et al. (2017) in Ghana, Beshir et al. (2012) and Challa \& Tilahun (2014) in Ethiopia, Obiero et al. (2019) in Kenya, that the larger production area owned by farmers, the more they will adopt modern technology. Furthermore, a contradictive thing from Israel mentioned by Yaron et al. (1992), was a small land area tend to adopt technology with input-intensive innovation.

Farmer group membership obtained positively and significantly affected decision with $p$-value $<0.10$ and value of the marginal effect of 0.2369 , which means that the average probability of geoisolator salt farmers who became a member in farmer group to make a decision was 23.69 percent higher than the average number of salt farmers who did not. Farmer membership in the group was used as an important aspect of access to geoisolator technology information. The important of farmer group membership in affecting adoption positively is also in agreement with several other studies, for example, Uaiene et al. (2009) in Mozambique, Asmelash (2014) in Ethiopia, Aryal et al. (2018) in India, (Twine et al. (2018) in Tanzania and Murage et al. (2019) in Kenya who reported that farmer in an agricultural organization will help a farmer to have access to credit, extension, and market.

Salt farmer participation in the extension had a positive and significant effect with $p$-value $<0.01$ and marginal effect value of 0.2697 , which means that the average probability of salt farmer to attend extension to decide on geoisolator implementation was 26.97 percent higher than that of farmers who did not attend the extension. This result is similar to study conducted by Beshir et al. (2012) and Asmelash (2014) in Ethiopia, Dhraief et al. (2018) in Tunisia, Kumar et al. (2018) in aquaculture and Obiero et al. (2019) in Kenya, Ahmed \& Anang (2019) in
Ghana that extension agents showed a significant effect on adoption level since the availability of information provided by extension agents is expected to stimulate adoption. The extension agent as a source of information related to geoisolator technology that has a strong influence on farmers' adoption decisions. At present, the availability of extension agents from the Ministry of Maritime Affairs and Fisheries in 2017 is very limited, in East Java Province only 505 extension agents. So that an extension agent is responsible for several villages, not only counseling about the saltworks but also fishponds. For work efficiency, an extension agent invites salt farmers in a predetermined location, but they cannot always follow counseling because the invitation is late received or they prefer to work on the saltworks because of the remote location.

\section{CONCLUSION}

Variables found to positively affect the decision of salt farmers to apply geoisolator technology were land area, salt farmer membership in a group, and salt farmer participation in extension. Moreover, variables observed to negatively affect included number of productive-age family members and the number of dependent family members. Increased adoption of geoisolator technology requires joint efforts from various parties. The government needs to add an adequate number of extension workers, the salt farmers group can be a bridge between the extension workers and salt farmers, so knowledge transfer will be obtained. The existence of salt farmers groups to share information can be realized, not just facilities to receive government assistance. Research on the factors that influence the decision of salt farmers in adopting geoisolator technology can add other variables such as variable assets owned by farmers, salt farmer income, and farmer motivation. 


\section{REFERENCES}

Adi, T. R., Supangat, A., Sulistiyo, B., Sukojo, B. M., Amarullah, H., Prihadi, T. H., Rustam, A. (2006). Buku Panduan Pengembangan Usaha Terpadu Garam dan Artemia. Jakarta: Badan Riset Kelautan dan Perikanan Departemen Kelautan dan Perikanan, RI.

Ahmed, H., \& Anang, B. T. (2019). Impact of Improved Variety Adoption on Farm Income in Tolon District of Ghana. Agricultural Social Economic Journal, 19(2), 105$115 . \quad$ https://doi.org/10.21776/ ub.agrise.2019.019.2.5

Akudugu, M. A., Guo, E., \& Dadzie, S. K. (2012). Adoption of Modern Agricultural Production Technologies by Farm Households in Ghana: What Factors Influence their Decisions? Journal of Biology, Agriculture and Healthcare, 2(3), 1-13. Retrieved from www.iiste.org

Allison, P. D. (2014). Measures of Fit for Logistic Regression. SAS Global Forum 2014, 2(1), 1-12.

Aryal, J. P., Rahut, D. B., Maharjan, S., \& Erenstein, O. (2018). Factors Affecting the Adoption of Multiple Climate-smart Agricultural Practices in the Indo-Gangetic Plains of India. Natural Resources Forum, 42(3), 141-158. https://doi. org/10.1111/1477-8947.12152

Asmelash, Y. (2014). Determinants of Adoption of Upland Rice Varieties in Fogera District, South Gondar, Ethiopia. Journal of Agricultural Extension and Rural Development, 8(12), 332-338. https://doi. org/10.5897/JAERD12.108
Balde, B. S., Kobayashi, H., Nohmi, M., Ishida, A., Matsumura, I., Esham, M., \& Tolno, E. (2013). Socioeconomic Analysis of Small-scale Salt Production Techniques in the Coastal Area of Guinea: as an Alternative for Improving Livelihood Status and Sustainable Mangrove Forest Management. International Journal of Research in Engineering, IT and Social Sciences, 3(9), 1-23. Retrieved from www.indusedu.org

Beshir, H., Emana, B., Kassa, B., \& Haji, J. (2012). Determinants of chemical fertilizer technology adoption in North eastern highlands of Ethiopia: the double hurdle approach. Journal of Research in Economics and International Finance (JREIF), 1(2), 39-49. Retrieved from http://www. interesjournals.org/JREIF

BPPP Tegal. (2017). Pembuatan Garam Rakyat dengan Teknologi Geomembran. Retrieved from http://www.bppp-tegal.com/web/ index.php/artikel/pegaraman/204pembuatan-garam-rakyat-denganteknologi-geomembran

Challa, M., \& Tilahun, U. (2014). Determinants and Impacts of Modern Agricultural Technology Adoption in West Wollega: The Case of Gulliso District. Journal of Biology, Agriculture and Healthcare, 4(20), 63-77. Retrieved from www.iiste.org

Coelli, T. J., Rao, D. S. P., O'Donnel, C. J., \& Battese, G. E. (2005). An Introduction to Efficiency an Introduction to Efficiency. Retrieved from springeronline.com 
Dhraief, M. Z., Bedhiaf-Romdhania, S., Dhehibib, B., Oueslati-Zlaouia, M., Jebali, O., \& Youssef, S. B. (2018). Factors Affecting the Adoption of Innovative Technologies by Livestock Farmers in Arid Area of Tunisia. FARA Research Report, 3(5), 1-22. https://doi.org/10.13140/ RG.2.2.15795.27686

Effendy, M., Zainuri, M. (2011). Intensifikasi lahan garam rakyat di kabupaten sumenep. 22-43.

Greene, W. H. (2012). Econometric Analysis 7 Edition. In Pearson (Vol. 7). https://doi.org/10.1017/ CBO9781107415324.004

Hu, Y., Li, B., Zhang, Z., \& Wang, J. (2019). Farm Size and Agricultural Technology Progress: Evidence from China. Journal of Rural Studies, (2). https://doi.org/10.1016/j. jrurstud.2019.01.009

Kassie, M., Zikhali, P., Manjur, K., \&Edwards, S. (2009). Adoption of Sustainable Agriculture Practices: Evidence from a Semi-arid Region of Ethiopia. Natural Resources Forum, 33(3), 189-198. https://doi.org/10.1111/ j.1477-8947.2009.01224.x.

Kementerian Kelautan dan Perikanan (2018). Marine and Fisheries Affairs in Figures 2018. Jakarta: Pusat Data, Statistik dan Informasi.

Kementerian Perindustrian. (2018). Kebutuhan Garam Industri Melonjak $76,19 \%$ di 2018. Retrieved from https://kemenperin.go.id/ artikel/18960/Kebutuhan-GaramIndustri-Melonjak-76,19-di-2018.

Kumar, G., Engle, C., \& Tucker, C. (2018). Factors Driving Aquaculture Technology Adoption. Journal of the World Aquaculture Society, 49(3), 447-476. https://doi.org/10.1111/ jwas.12514
Letaa, E., Kabungo, C., Katungi, E., Ojara, M., \& Ndunguru, A. (2015). Farm Level Adoption and Spatial Diffusion of Improved Common Bean Varieties in Southern Highlands of Tanzania. African Crop Science Journal, 23(3), 261-277.

Mignouna, D. B., Manyong, V. M., Rusike, J., Mutabazi, K. D. S., \& Senkondo, E. M. (2011). Determinants of Adopting Imazapyr-resistant Maize Technologies and its Impact on Household Income in Western Kenya. AgBioForum, 14(3), 158163.

Murage, F.M., Mugwe, J.N., Ngetich, K.F., Mucheru-Muna, M.M. and Mugendi, D. N. (2019). Adoption of Soybean by Smallholder Farmers in the Central Highlands of Kenya. African Journal of Agricultural Economics and Rural Development, 7(5), 1-12. Retrieved from www. internationalscholarsjournals.org

Muzari, W., Gatsi, W., \& Muvhunzi, S. (2012). The Impacts of Technology Adoption on Smallholder Agricultural Productivity in Sub-Saharan Africa: A Review. Journal of Sustainable Development, 5(8), 69-77. https:// doi.org/10.5539/jsd.v5n8p69

Nazir, A., Li, G., Inayat, S., Iqbal, M. A., Humayoon, A., \& Akhtar, S. (2018). Determinants for Income Diversification by Farm Households in Pakistan. The Journal of Animal \& Plant Sciences, 28(4), 1163-1173.

Obiero, K. O., Waidbacher, H., Nyawanda, B. O., Munguti, J. M., Manyala, J. O., \& Kaunda-Arara, B. (2019). Predicting Uptake of Aquaculture Technologies Among Smallholder Fish Farmers in Kenya. Aquaculture International, 27(6), 1689-1707. https://doi.org/10.1007/s10499-01900423-0 
Rogers, E. M. (2003). Diffusion of Innovations Fifth Edition. New York: Free Press.

Samiee, A., Rezvanfar, A., \& Faham, E. (2009). Factors Influencing the Adoption of Integrated Pest Management (IPM) by Wheat Growers in Varamin County, Iran. African Journal of Agricultural Research, 4(5), 491-497. Retrieved from http://www.academicjournals. org/AJAR

Scheirs, J. (2009). A Guide to Polymeric Geomembranes. Chennai: Wiley.

Sedivy, V. M. (2009). Environmental Balance of Salt Production Speaks in Favour of Solar Saltworks. Global Nest Journal, 11(1), 41-48. https:// doi.org/10.30955/gnj.000567

Suhendra, A. (2016). Increasing the Productivity of Salt through HDPE Geomembrane - Indonesian Case History in Salt Evaporation Pond. Ejge, 21, 4273-4280. Retrieved from http://www.ejge.com/2016/ Ppr2016.0363ma.pdf

Susanto, H., Rokhati, N., \& Santosa, G. W. (2015). Development of Traditional Salt Production Process for Improving Product Quantity and Quality in Jepara District, Central Java, Indonesia. Procedia Environmental Sciences, 23(Ictcred 2014), 175-178. https://doi. org/10.1016/j.proenv.2015.01.027
Twine, E. E., Rao, E. J. O., Baltenweck, I., \& Omore, A. O. (2018). Are Technology Adoption and Collective Action Important in Accessing Credit? Evidence from Milk Producers in Tanzania. European Journal of Development Research, 31(3), 388412. https://doi.org/10.1057/s41287018-0158-z

Uaiene, R. N., Arndt, C., \& Masters, W. A. (2009). Determinants of Agricultural Technology Adoption in.

Udimal, T. B., Jincai, Z., Mensah, O. S., \& Caesar, A. E. (2017). Factors Influencing the Agricultural Technology Adoption: The Case of Improved Rice Varieties (Nerica) in the Northern Region, Ghana. Journal of Economics and Sustainable Development, 8(8), 2222-1700. Retrieved from www.iiste.org

Yaron, D., Voet, H., \& Dinar, A. (1992). Innovations on Family Farms: The Nazareth Region in Israel. American Journal of Agricultural Economics, 74(2), 361-370. https:// doi.org/10.2307/1242490 